\title{
In memoriam: Prof. Dr. José Roberto Giglio and his contributions to toxinology
}

\author{
A B S T R A C T
}

\section{Keywords:}

In memoriam

Prof. Dr. Jose Roberto Giglio

Toxinology
Prof. Dr. José R. Giglio (1934-2014) made a highly significant contribution to the field of Toxinology. During 48 years devoted to research and teaching Prof Giglio published more than 160 articles, with more than 4400 citations, in international journals, trained a vast amount of graduate and undergraduate students, and developed an international network of collaborators. Throughout these years, he worked with dedication and deep commitment to science, leaving an immortalized legacy. During his professional career he contributed mostly in the isolation, and biochemical and functional characterization of various protein toxins derived from animal venoms such as snakes, scorpions and spiders, in addition to his studies searching for alternative therapies for poisoning. Even after his departure, his presence and influence remains among his former students and in the outstanding legacy of his scientific contributions.

\section{Introduction}

When, on the morning of April 10, 2014, I received by telephone the news of the death of Prof. Dr. José R. Giglio (Fig. 1), a huge sense of loss and sadness came over my mind, just as his family and his many friends and disciples were feeling at the time. We became poorer, his family and friends for the loss of a loved one, Brazil and the world for the loss of an outstanding chemist and toxinologist.

Before presenting a brief biography of Professor Giglio, I would like to relate some memorable episodes I witnessed during his life that illustrate his modest and generous personality, as well as to leave the testimonies of researchers who knew him. I met Prof. Giglio in January of 1995 during the selection process of prospective Master students at the Ribeirão Preto College of Medicine; he initially refused (three times) to be my advisor at the Biochemistry Program, however, he made a point to introduce me personally to other teachers in the same department. Upon my insistence to a scientist of short stature and modest expression, in a brief moment of reflection, the noble heart spoke louder, and Prof. Giglio decided to take on one more student among his many disciples, becoming a giant to me due to the depth of his technical and scientific knowledge. He became an active advisor and even forceful in his convictions, contributing solidly to the scientific training of his disciples. With an extreme ability to identify and encourage leaders in his laboratory, Professor Giglio was instrumental to the consolidation of my professional career when he supported unquestioningly my first research project to be submitted to FAPESP in 1997. When choosing the project title, he said I could submit it because he believed in my potential and had already had other opportunities to evaluate my work. He was an example of the ever-present mentor, insightful, challenging, ethical and, above all, a committed friend, always concerned with the consolidated training of future independent researchers.

Now I would like to relate the opinion of another major researcher in the field of Toxinology, Professor Dr. José María Gutiérrez (Instituto Clodomiro Picado, ICP, Universidad de Costa Rica, UCR, San José, Costa Rica, Central American), to contribute to this small posthumous tribute to Prof. Giglio. The following is a statement sent by Prof. Gutiérrez: "Prof Giglio is one of the most outstanding scientists in the field of Toxinology. His main contributions are in the isolation and biochemical characterization of toxins from snakes and other venomous animals. His studies on myotoxic phospholipases $A_{2}$ represent a landmark in this field, as well as his contributions to the characterization of venom proteinases and other types of toxins. He was a brilliant biochemist. In addition, he devoted his interest to the search of inhibitory substances against venom components, with relevant contributions in this topic as well. Beyond his professional side, on the occasions I had the opportunity to share some time with him, I came to 


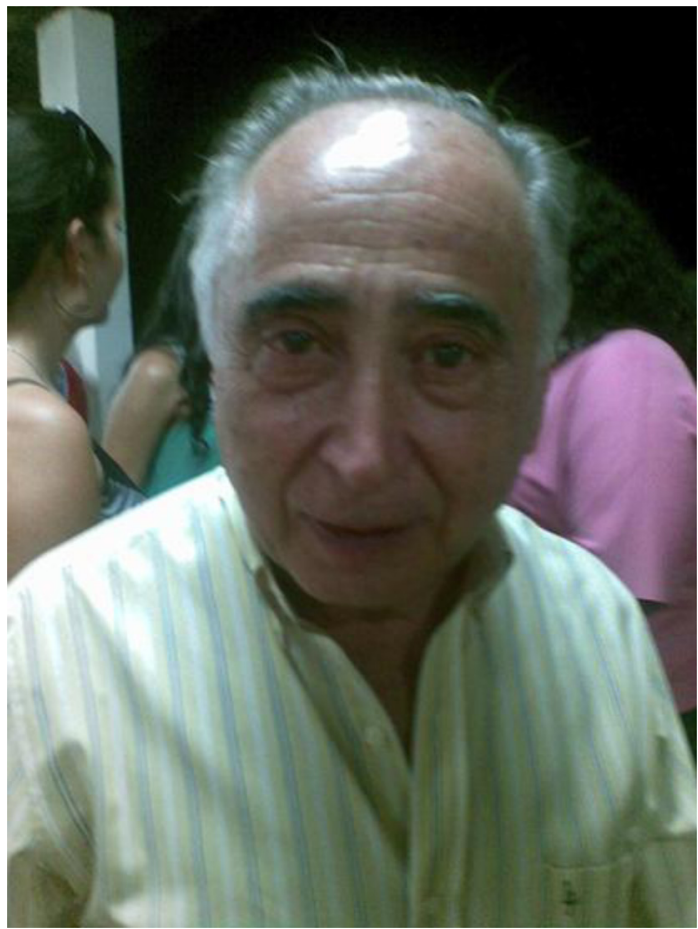

Fig. 1. A recent photo of Prof. Dr. José Roberto Giglio.

appreciate his human profile, as he was a very gentle and modest person, with a good sense of humor and with the capacity to listen and care for other people. His physical departure is a big loss for the toxinological community of Brazil and the rest of the world, but his academic and human legacy will persist for a long time."

Prof Giglio was born in 1934 in São Paulo. He graduated in Chemistry in the College of Philosophy, Sciences and Letters, University of São Paulo - USP, and of a group of 30 admitted in 1954, only five graduated in 1957 . He became a teacher of Chemistry at Osvaldo Cruz High School where he taught classes from 1957 to 1958, and between 1958 and 1959 he collaborated with the Cancer Hospital of São Paulo, working in the Chemistry Laboratory. In 1959, he was appointed to work in the Department of Biochemistry at Ribeirão Preto College of Medicine (FMRP-USP), together with Prof. Dr. José Moura Gonçalves, as Professor of Biochemistry. He promptly presented himself for the position and also started his first research project on snake venoms. It was then when he met his wife, Albertina E. Giglio, whom he married in January of 1962 and took up residence on the University campus, where he resided for 40 years. Dr. Giglio has three children and six grandchildren, a family with solid structure which he built simultaneously with his academic career (Soares et al., 2007).

He directly began his PhD in 1959, with the project entitled "Amino acid terminals of crotamine", concluding it in 1962 in the area of Biochemistry of the University of São Paulo-USP, under the orientation of Prof. Gonçalves. In his first stay abroad, he learned to perform amino acid analysis, being responsible for the purification and determination of the amino acid composition of crotamine, which was the first of these analyses in Brazil. In the period from 1969 to
1980, Dr. Giglio published 10 articles related to bovine thrombin and prothrombin, pork and lamb products, with his first publication about animal venom toxins (analytical studies about crotamine) published in 1975 (Giglio, 1975). From 1975 to 1976 he worked at Imperial College in London as a visiting professor, where he learned to do manual sequencing of peptides and proteins (for more details, see Soares et al., 2007).

Linked to the Department of Biochemistry, at the Ribeirão Preto College of Medicine, University of São Paulo (FMRP-USP), he became a professor in 1990, dedicating his life to teaching and research, preparing graduate students for their MSc and PhD degrees helping new researchers and building disciples. In the period from 1969 to 2013, Dr. Giglio published 165 articles cited 4486 times with a factor $h=40$, parameters that demonstrate his effective dedication to the development of science in Brazil and his contribution to Toxinology on a global basis. Prof. Giglio has four articles with more than 100 citations each, listed here in descending order of citations published in Toxicon $>\mathrm{J}$. Biol. Chem. > J. Prot. Chem. > Arch. Biochem. Biophys. All refer to papers about animal venoms, from the first description of the isolation and characterization of Bothropstoxin-I from Bothrops jararacussu venom (HomsiBrandenburgo et al., 1988), to the determination of the primary structure of BthTX-I from $B$. jararacussu venom (Cintra et al., 1993), to the characterization of the myotoxin from Bothrops neuwiedi pauloensis (Soares et al., 2000). His last publication and the result of his last position as Master's advisor, came out in December 2013 in the French journal Biochimie; the paper reports the biochemical and structural studies of intercro, a free isoform of phospholipase $A_{2}$ found in the venom of the South American rattlesnake, Crotalus d. terrificus (Vieira et al., 2013).

On May 21, 1995, the names of 170 renowned Brazilian scientists were published in the newspaper "Folha de São Paulo" ( $0.85 \%$ of the Brazilian scientific community), among them Professor Giglio, whose work had the greatest impact among his peers in the world, according to a study from a database of the ISI (Institute for Scientific Information, USA). He was also recognized by National Counsel of Technological and Scientific Development (CNPq), being honored as an Emeritus Researcher (Soares et al., 2007). His main qualities are dignity, character and love for the profession. In his own words, in homage to his 73 years of life, he said "I have a feeling of accomplishment, but even conscious of that, I still reach out to those who need valuable knowledge" (Soares et al., 2007).

\section{Acknowledgments}

The author is grateful to Dr. José M. Gutiérrez (ICP, UCR, Costa Rica) for critical reading of this manuscript and Ms. Amy Nicole Grabner provided the English editing of the manuscript.

\section{References}

Cintra, A.C., Marangoni, S., Oliveira, B., Giglio, J.R., 1993. Bothropstoxin-I amino acid sequence and function. J. Protein Chem. 12, 57-64. 
Giglio, J.R., 1975. Analytical studies on crotamine hydrochloride. Anal. Biochem. 69, 207-221.

Homsi-Brandeburgo, M.I., Queiroz, L.S. Santo-Neto, H., RodriguesSimioni, L., Giglio, J.R., 1988. Fractionation of Bothrops jararacussu snake venom: partial chemical characterization and biological activity of bothropstoxin. Toxicon 26, 615-627.

Soares, A.M., Guerra-Sa, R., Borja-Oliveira, C.R., Rodrigues, V.M., Rodrigues-Simioni, L., Rodrigues, V., Fontes, M.R.M., Lomonte, B., Gutiérrez, J.M., Giglio, J.R., 2000. Structural and functional characterization of BnSP-7, a Lys49 myotoxic phospholipase $A_{2}$ homologue from Bothrops neuwiedi pauloensis venom. Arch. Biochem. Biophys. 378, 201-209.

Soares, A.M., Oliveira, C.Z., Sant'Ana, C.D., Menaldo, D.L., Silveira, L.B., Teixeira, S.S., Rueda, A.Q., Marcussi, S., 2007. Professor José Roberto Giglio and toxinology in Brazil: 48 years in research. REVIEW. J. Venom. Animals Toxins Incl. Tropical Dis. 13, 711-728.

Vieira, L.F., Magro, A.J., Fernandes, C.A.H., Souza, B.M., Cavalcante, W.L.G., Palma, M.S., Rosa, J.C., Fuly, A.L., Fontes, M.R.M., Gallacci, M.,
Butzke, D.S., Calderon, L.A., Stábeli, R.G., Giglio, J.R., Soares, A.M., 2013. Biochemical, functional, structural and phylogenetic studies on Intercro, a new isoform phospholipase $\mathrm{A}_{2}$ from Crotalus durissus terrificus snake venom. Biochimie 95, 2365-2375.

Andreimar M. Soares Centro de Estudos de Biomoléculas Aplicadas à Saúde "Prof. Dr. José Roberto Giglio", CEBio, Fiocruz Rondônia e

Universidade Federal de Rondônia, Porto Velho, RO, Brazil E-mail addresses: andreimar@fiocruz.br, andreims@hotmail.com (A.M. Soares)

3 May 2014 Available online 10 July 2014 